\title{
日本内科学会に望むこと
}

\section{井村 裕夫}

Key words : 統合の医学, 臨床研究, トランスレーショナル・リサーチ, 医学教育

はじめに

日本内科学会の 100 年は,ほほ 20 世紀に相当 する. 20 世紀における内科学の進歩を一言で表 現すれば, 経験の学問から科学に基づく内科学 への移行であろう. 生化学, 生理学, 画像医学 の進歩が，この移行を促した．そして科学の方 法論に従って, 内科学は二つの方向に大きく変 化した。一つは専門への分化で, システム別の 分科学, 循環器病学, 消化器病学などが発展し た。それぞれの分科は固有の䛦断・治療技術を 発展させたため，多くの内科医はそれらを修得 するのに多大な時間を使うようになり，勢い分 科学の專門家となってしまった. そのことへの 反省から, 総合診療部が作られたり, プライマ リ・ケアーの重要性が叫ばれたりしたが, 専門 化の流れはとまっていない. それが, 近代科学 の大きい特徴だからである. そのため日本内科 学会は, 異分野の専門家の交流の場, 異分野の 新知識の教育の場となった。

いま一つの大きい変化は, 近代科学の特徴で ある還元主義の内科学への導入である. 病気の
現象論から始まり，その成因を精細に分析して 最終的には分子，遺伝子のレベルに達する。そ れは原子から素粒子へと達した近代物理学の手 法をなぞるものであった。そしてこのような還 元主義の総仕上げとしてヒトゲノム・プロジェ クトが進められ，2001 年には粗稿が発表され， 2003 年には最終稿が完成する.人間は自分の体 を構成する素子の設計図を今手に入れようとし ている。 それは精密科学としての医学あるいは 生命科学の輝かしい成果であることは疑いがな W.

ゲノムの解読は，たしかに多くの情報をわれ われに与えてくれるであろう.しかし，生命の 仕組みは決してそれ程単純なものではない. 21 世紀の医学では，ゲノムを基礎としてもう一度 生命体を再構成する努力を拂わねばならない。 そこには偶然や，環境因子や，遺伝子の個人差 など,多くの要因が関与するものと考えられる. 分析の時代から統合の時代に向かう医学, “ここ ろ”を含め人全体が問題となる医学，その中で 内科学会がどのような役割を果たすべきか, そ れに対する私見と期待を述べる.

\section{いむらひろお：日本内科学会名兴会貝}




\section{1. 日本内科学会への期待}

\section{1）統合の医学の先導}

ヒトゲノムの解読の結果，ヒトの遺伝子数は 予想よりも少ないことが明らかになった。従っ て遺伝子の転写後に様々な修飾が起こることが 予想され，RNA，タンパク質などが，ポストゲ ノム研究の焦点となっている. また遺伝子の個 人差 (多型) が疾患への感受性や薬物への応答 の個人による違いを決定するものと考えられ， 一塩基多型（SNPs）がテーラード医学への道を 開くものとして注目されている．とくに内科診 療で日常よく遭遇するいわゆる common disease の成因の解明には, SNPsやハプロタイプのよう な遺伝子多型の研究は不可欠である.しかしこ れらの疾患には同時に環境因子も大きく関与し ており，今後遺伝子と環境要因の関わりを様々 なレベルで研究しなければならない。また“こ ころ"と体の関係を明らかにすることも，一部 の病気の成因の解明には必要である。ポストゲ ノム研究, それは遺伝子から個体に向けての道 筋を辿る統合の科学となるものと考えられる.

このような時代にあっては，内科学の果たす 役割は大きい，それは内科学こそは，人間を丸 ごと対象とするすぐれて総合的な学問であるか らである.ポストゲノム研究の時代にあっては, 生み出される膨大な情報を基盤として個体の医 学を構成しなければならない。それにはバイオ インフォーマティクス, システム生物学など異 分野の研究者との共同研究が不可欠となってく る. 日本内科学会も内科学の専門家だけでなく, 他の分野の研究者も招聘して新しい統合の医学 を先導してほしいと期待している。

2）狭義の臨床研究,とくにトランスレーショ ナル・リサーチ（TR）の推進

臨床研究には, 直接患者を対象として診断・ 治療法の開発を行う患者指向型（patient-oriented) 研究と, 遺伝子, 細胞, 血液などの試料を
用いて病因などを研究する疾患指向型 (diseaseoriented) 研究とがある、狭義の臨床研究は前者 で, 新しい薬物の有効性を確かめる治験, 発売 された薬郕の疾患や予後への影響を明らかにす る臨床試験，その他の新しい診断・治療法の開 発や臨床疫学などの臨床研究が含まれる.この 分野は従来わが国では研究が遅れていた，その 証拠に狭義の臨床研究の専門誌であるNew England Journal of MedicineやLancetへのわが国の 寄与率は, 他の分野に比し著しく低い。

ゲノムをはじめ基礎研究の進歩が極めて著し い中で，それを迅速に臨床に応用するためTR という考え方が登場してきた。基礎研究の段階 から目標を設定し，異分野の専門家が協力して 戦略的に臨床へ展開しようとする新しい型の研 究で, 臨床研究の一部と言える。医学研究者以 外に, 臨床統計学者, 医用工学者, 臨床研究コー ディネーターなど様々な分野の専門家の協力と， 計画的, 総合的に研究を推進するためのマネー ジメントが求められる．医薬品も含め，新しい 医療技術の開発には国際競争が極めて激しいの で,TRの推進には政府の積極的な支援が必要で ある。しかし，TRの中心は内科学であるので， 日本内科学会もTRを含む臨床研究の推進のため, 人材の育成, 臨床研究者の意識改革, すぐれた 臨床研究の顕彰など, 様々な施策を実施される ことを期待したい。

\section{3）内科医の教育}

日本の医学教育は卒前, 卒後を含めて大きい 変革期にある．卒前教育では生涯学び続ける姿 勢を如何に植えつけるか，患者やその家族と良 好な人間関係を如何に保つか，指導しなければ ならないことは多い。とくに全世界で通用する EBMに基づく医療を教え込むことが必要である. 医学教育の標準化に，日本内科学会も大きい役 割を果たしてほしい。

卒後教育も卒後研修の必修制を目前に控えて 大きく変わろうとしている．それは従来のいわ ゆる医局講座制を大きく摇るがすことになるか 
も知れない. 何よりも大切なことは良い医師を 作るための卒後研修をどう構築するかであり， その視点に立って日本の医系大学は新しいあり 方を模索しなければならない。卒後研修の中心 はあくまでも一般内科学であり, 学会の先導が 期待される.

むすび

日本内科学会への期待を, 思いつくままに挙
げてみた. 21 世紀, 科学としての医学は一層進 歩するであろう.しかし医学は科学のみでなく， それを基礎とした癒しの学問でなければならな い.そこに臨床医学の特異性がある。日本の内 科学会はそうした学問の発展を先導するのみで なく，わが国の医学のあり方について積極的な 発言ができる組織となってほしい. 